\title{
Sri Lankan women migrant workers and role of family and kinship networks
}

\author{
Shantha Wanninayake ${ }^{1, *}$ \\ ${ }^{1}$ Senior Lecturer, Department of Sociology, University of Peradeniya, Sri Lanka
}

\author{
Keywords: \\ Women \\ Migrant workers \\ Family \\ Kinship \\ Networks
}

Received: 12 December 2015

Accepted: 16 January 2016

Published: 22 Feburary 2016

\begin{abstract}
This paper explores the impact of women's migration on the family network and kinship relation and the found success achieved by their families. Particularly, when a woman leaves her family for foreign employment, instantly gaps and challenges arrive regarding the family's security and taking care of children. In such situations, how do the family network and kinship networks operate, and with what effect? The study shows that when the woman is absent, family members fill the gaps and share the service as well as how they managed, controlled, consumed, saved, or invested remittance received as foreign earning by using their family and kinship networks. The study covered the two DS Divisions in the administrative district of Kurunegala in North Western Province in Sri Lanka and selected a random sample for collecting data. The study mainly depends on qualitative data using in-depth interviews, interviews with key informants.
\end{abstract}

C 2016 The Author. Published by TAF Publishing.

\section{INTRODUCTION}

Substantially important and interesting studies have been made on Sri Lankan labour migration to foreign countries, which have remained at on increasing tread over the last two decades. Various research organizations, institutions as well as individual researchers have studied and analyzed this trend both at macro and micro levels by using a variety of approaches. Most of the studies at macro level have been used to analyze data on the importance of migration as a means of foreign exchange earnings and alternative solutions provided for poverty alleviation and to solve the unemployment problem. Also the tendency towards contemporary labour migration has been studied (Syed, 2016). Most of these studies have attempted to examine the contribution made by foreign earnings towards improving the economic conditions of the family, community and the national economy (man power planning division of the ministry of plan implementation 1980, Department of labour 1981) some of the micro level studies have pointed out that particularly for the women, the family and the community women's migration in important both from the economic and socio-

\footnotetext{
* Corresponding author: Shantha Wanninayake

E-mail: shanthaw@pdn.ac.lk, shanthaw2003@yahoo.com
} 
cultural aspect (Colen 1995; Gunathilaka 1992; Wanninayaka 2001; Wanninayake, 2006; Lee. 2013).The aim of this paper in to explore the impact created by women's migration on the respective family network and kinship relation and the find success achieved by their families from on anthropological view point. Particularly, when a woman leaves her family for foreign employment, instantly gaps and challenges arrive regarding the security of the family and taking care of children. In such situations when and how does the family network and kinship networks operate, and with what effect? When the migrated, labour remit foreign exchange earnings, how are the benefits managed, controlled, consumed, saved or invested. Regarding there aspect how does kinship net works operate? Such questions demand in-depth analysis.

In anthological research, attention has been focused on kinship and family, over a long span of time. However such studies with a focus on international labour migration were started only recently. The pioneers in this regard are Collier and Sylvia (1987) and Gamburd (1995). Collier and Sylvia (1987) state that in relation to kinship and gender studies, findings from the western counties cannot be generalized and applied to then societies. Gamburd (1995) has observed that as a woman enters the arena of international labour migration, impacts are created in the areas of socio-economic and political on the family, community and the society as a whole. However these studies have not revealed the direct impacts created by the women on her kinship and family networks in tears of successes reaped by kinship through the social net works between the two parties.

The objective of this study in to explore the contribution made by woman and the cooperation of the kinship net works to achieve success in improving her family. This means that the effectiveness of the woman conserved and her social institutions is not the main dependant factor. The successfulness of the returnees in influenced by many factors (Wanninayaka, 2001). However it has been observed that the co-operation between the family and kinship group and the network relationships existing among them plays a significant role. While it is assumed that a woman's migration out of the family leads to stress within the family and failovers in subject to a substantial challenge. There is no intention to state that the success of a woman and her family does not solely depend on money accumulated or economic wealth built up by working abroad. Although the economic contribution though earnings is essential to achieve success, what is more important in to analyze turn an anthropological approach haw the woman and her family use the family network face the behavioral changes are their went to success. On the other hand the natural linkages that exist at the national and international levels or could be developed by the individual concerned also deserve attention.

In gathering data for this study qualitative information was given more attention than for quantitative information. Basically a single case study was the significant factor around which venison phenomena were qualitatively analyzed to explain the findings. Although some one may see this effort as a isolated event with it over beginning and end, this study aimed to explore some of the unobserved phenomena related to women's migration, and also to identify ways and means to some of the problems associated with women's migration. Also some of the traditional kinship patterns have been changing and they appear to 
be gradually fading away in the complicated and continuously changing social contexts. Some of the national an international labour migration treads.

\section{A Brief History of Sri Lankan's Migration}

Constant movement of people within and across national boundaries is a key feature of the contemporary era of globalization (Appadurai, 2001). Sri Lanka is no exception to this global pattern. Nearly 23 percent of the Sri Lankan workforce is currently employed abroad, mostly in contractual labour and domestic work in the Middle Eastern region. Sri Lankan migrant workers, however, are spread out all over the world, including South Korea, Singapore, Japan, Malaysia, Maldives, Italy, Cyprus, Seychelles, Nigeria and many other countries. In 2009 remittances from overseas employment contributed to nearly 8 percent of GDP and were the leading source of foreign exchange in Sri Lanka, overshadowing foreign aid, Foreign Direct Investments and export incomes (Sri Lanka Bureau of Foreign Employment (SLBFE), 1997-2014). This highlights the significance of overseas employment as a source of employment on the one hand and as a source of foreign exchange for the Sri Lankan economy on the other. In addition, a range of Sri Lankans including students who are eager to study abroad, men and women who are eager to find employment overseas and those who seek to migrate to foreign destinations as legal migrants, refugees or even as illegal migrants indicate the growing significance of international migration for Sri Lankans. Several criteria such as gender, age, a wealth owned by the house hold, urban/ rural differentiation civil states, education nature of employment, ethnicity and caste may influence the decision to go abroad for employment. However, at present remittances by women working abroad makes a significant contribution to the country's economy. This change could inevitably be licked to changes on the society, culture and political changes.

\section{Gender and Foreign Employment}

While males outnumbered females among overseas migrant workers from Sri Lanka in the 1980s, the pattern reversed from 1990 onwards with female migrant workers vastly outnumbering their male counterparts from 1994 to 2005 or so. As of 2009 male outmigration caught up with female outmigration due to the opening of new employment opportunities for male migrant workers from Sri Lanka in South Korea and a number of other destinations. By comparison to male migrant workers, a vast majority of female migrant workers from Sri Lanka continued to work as housemaids even in 2009.

\section{Study Area}

Field work for this study was done in "Ihalagama" village, in Maho divisional secretary's division in Kurunagala district with in North Western Province of Sri Lanka. This is a rural area within the dry Zone. 


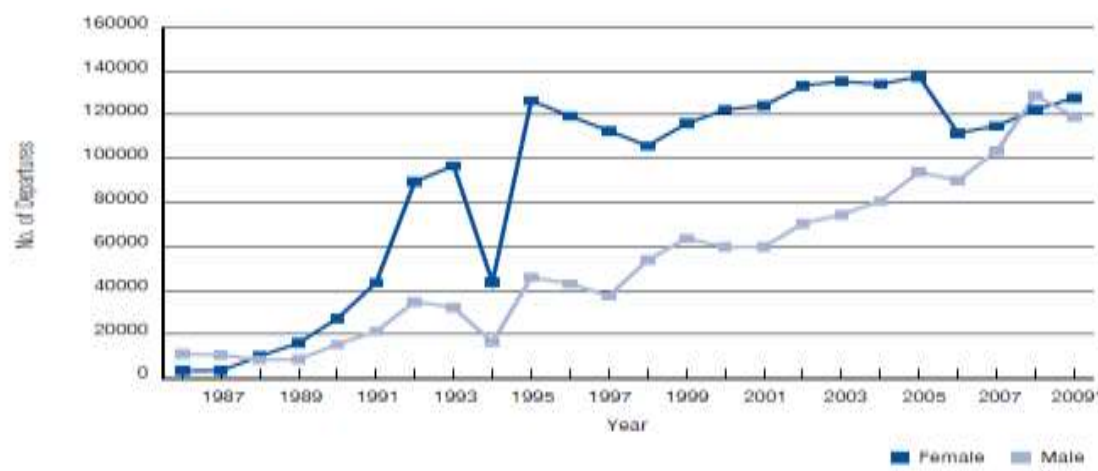

Source: (SLBFE, 2010)

FIGURE 1. Departure for foreign employment by sex 1986-2009

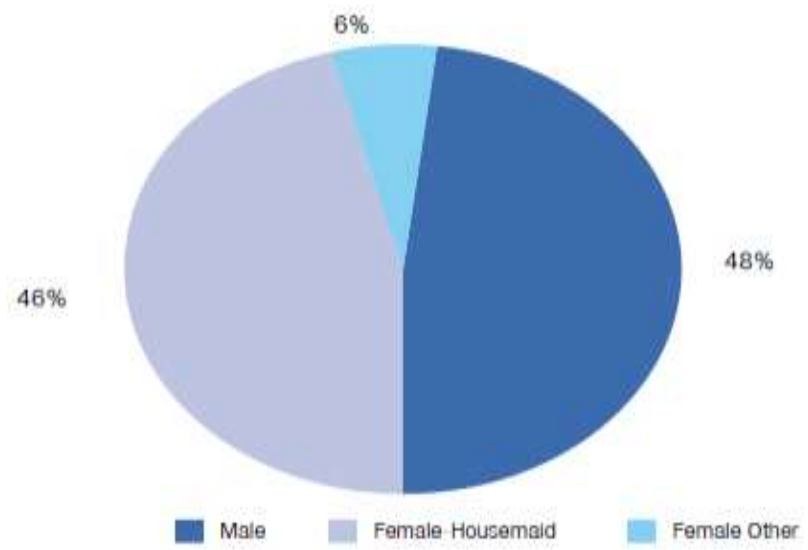

Source: (SLBFE, 2010)

FIGURE 2. Comparison of male migrant workers, housemaids and other female migrant workers 2009

Maho divisional secretary DS division is 24756 square kilometers in extent. It comprises of 68 Grams Niladhari Divisions covering 204 villages the total population in Mario DS division is 60315.The population includes 3 ethnic groups namely Sinhala-Tamils and Moslem.

The main source of livelihood of the majority of the population is farming. Home gardening is also somewhat important for the local population, and coconut is cultivated in the home gardens. In Ihalagama village top priority is given for paddy cultivation and farming. A few individuals are engaged in different occupations to earn an income. A few of them are in the middle-class including clerks and teachers. However their presence in the village has not created any significant changes in the village.

Although more than $80 \%$ of the population in the village depend or farming to earn their livelihood, their daily routine has not improved. The basic challenges they confront are constructing of reasonably good dwellings, shortage of water, drought as well as satisfying there day-to-day consumption needs. To solve these problems people attempt in venison ways. The villagers 
have focused their attention to earn money from sources beyond the village boundary since economic prospects within the village are scarce.

\section{Background Factor for Migration and New Trends}

The relative importance of foreign employment (mostly domestic work in the Middle East) among women in this community is mainly due to lack of alternative employment. Lacking educational qualifications and social contacts with powerful people in society and as members of a hereditarily disadvantaged community, they have limited avenues for making any headway in their lives. Overseas migration for work as housemaids is pursued also as a means of escaping social marginalization and domestic problems. Many migrant workers from this community helped each other in securing and sustaining overseas employment through a pattern well documented by Gamburd in the community where she studied. This indicates that foreign employment in such communities is not merely a matter of individual choice but also a collective enterprise where networking is involved.

In recent times Sri Lankan media has given wide publicity to violence and trauma experienced by female overseas migrant workers from Sri Lanka, particularly in countries in the Gulf region. The widely publicized tragic stories of persons like Rizana Nefeek who suffered death sentence in Saudi Arabia have evoked strong sentiments in Sri Lanka. In order to stem the flow of female migrant workers for overseas domestic work, the government has also introduced some new measures such as banning migration of women with children below years of age. In spite of these restrictions and bad publicity, there is no sign of any reduced enthusiasm for overseas migration among women or men. This in turn calls for a closer examination of the economic and social motivations for overseas migration among the women in particular.

Although there were some bad impression and negative result for foreign employment, we can identify some success stories among them. Particularly with linkages between a family and kinship, building up structural relationships can contribute in a big way forwards family stability. These were some success fat families and the secret of their success was strong linkages between the family and kinship group. The case study of "Leela is one good example".

\section{A Success Story}

The central figure in this case study is Leela, a woman who was 57 years old at the time of this study. She lost her husband due to snake bite when she was 32 years old. She had a son and two daughters. At the time her husband's death her son was 14 years old and two daughters were 12 and 8 respectively. Leela's mother who was an elderly woman too was living with them. They had limited assets. They made a living from small farm land her husband had inherited. After his death life became extremely difficult for the entire family. She was the eldest daughter in her family with two sisters and one brother who all respected her and saw her as a source of help and advise when they had difficulties. This case study represents the rural poor listed in the earlier section. Unfortunately no information about the caste background of the family is available.

With few options in life Leela went to Dubai in 1986, when she was 34 year old, to work as a housemaid in a house with 8 members including the two 
parents. Her initial inspiration to go for overseas work came from a classificatory sister in a nearby town who had returned from overseas work and two other women from her own village who were working overseas at the time. Leela was impressed by earnings of these known migrant women and the presents they brought to their families when they returned home including clothing, electrical appliances. From her classificatory sister Leela came to know that the work in the house where she was employed was not that demanding even though the situation was more difficult in some of overseas households where Sri Lankan women were employed. She also frequently mentioned about the attraction of air travel, foreign exposure and the importance of maintaining a good relationship with the family of the employer. Further this classificatory sister was eager to go back to Dubai.

In order to pay for the employment agency Leela had to borrow money from her two sisters and her classificatory sister who was already working abroad. She also mortgaged the paddy field she inherited from her husband. Leela's mother objected to her plan to go abroad leaving behind small children but in the end she opted to look after the children when she was away. Leela's two sisters who were living in nearby houses also came forward to help them when needed. Further Leela had a younger brother living some distance away and she arranged him to come and visit his mother and her grand children from time to time in order to enhance their support base.

Leela had to work hard and get accustomed to a foreign culture. Her day started at 5 am and often extended up to midnight or beyond. She worked in a multistoried house where relatives of the employer family lived in upper and lower floors. Apart from serving the employer family, Leela had to assist their relatives in different floors as well with no extra payment for such work. It was hard to satisfy the wife and children in the employer family even though she was pleased that the male head of the household was a kind-hearted man. The work included house cleaning, toilet cleaning, washing, child care, cooking and a variety of other duties as well.

Leela sent her first remittance to her sister, Sheela, after three months of work, requesting her to spend the money on Leela's three children who were in custody of Leela's mother. She worked in the same house for two years and saved some of her earnings in a bank account opened for her by her employer.

\section{Recruitment of her Family Members for Work in Dubai}

Leela came to know that the Arabic employer family is seeking to recruit another domestic worker in order to cope with the additional work generated in the household. Leela quickly contacted her sister Pathma who agreed to join her in Dubai and the employers arranged to bring her down within one month. Leela was much relieved after her sister joined her because there was some one to discuss personal problems and she managed to share her duties with her sister. Both of them worked with much enthusiasm thereafter. Leela became primarily responsible for cooking with part of other duties assigned to her sister. The work became much more efficient and neat and tidy thereafter the employer family too quickly noticed it. As a result they gave presents to both Leela and Pathma as well as their children who were living in Sri Lanka.

As time went by, Leela came to know that an opening for a domestic helper has arisen among the relatives of her employer living in the upper floor. Their 
former helper who was a Filipina had left due to a disagreement over salaries. Leela knew this situation but she decided to get down her second sister Sheela for this opening. So a third member of her family joined her in Dubai adding to their social network. Even though they were in the same building daily contact with Sheela was not possible as they were in different floors. The fact that Leela was already well established in her work and both Leela and Pathma had good record with their employer family served to provide a conducive work environment for Sheela too. The social network among the three female migrant workers from the same family served as a mutual support mechanism not only in daily life but also in their dealings with the employer families.

Leela came back to Sri Lanka two years and two months after she initially left the country with the intension of going back. She brought many presents not only for her mother and children, but also family members of her two sisters working Dubai as well as members of her brothers family living some distance away. Leela arranged the wedding of her daughter during this visit. Further she took steps to help the husbands of her two sisters who were working in Dubai to expand their livelihoods in Sri Lanka. For instance, as one of them was a carpenter, Leela helped him acquire some new tools with the help of which he managed to expand his operation. She came to know that her other brother in law was getting addicted to alcohol and she used this opportunity to advise him against it and reportedly she was successful in compelling him to regulate his addiction.

Leela used her earnings in the first two years to finance the wedding of her daughter, lay the foundation for a new house, pay back the loans she had taken and meet the requirements of her other children and her old mother. She went back to her employer in Dubai after a few months and worked there for another 4 years. Eventually she returned to Sri Lanka permanently after her mother died and she arranged for her own children to join middle east migration since then. Her son Piyal who was a driver and who was married went to the same household where Leela worked as a driver in 1993. Leela's sisters who were working in Dubai helped him acquire this job. Later Piyal got down his wife too to work as a domestic helper in a nearby house. Later Leela's youngest daughter, Champa who was a 19 years old unmarried woman, also went to Dubai as a house maid in a house known to Leela's original employers. This opening was made available to Champa by her brother and mothers' two sisters who were still working in Dubai. Champa however faced some difficulty in her work place as her employer's oldest son made some advances to her. She, however, was able to overcome this problem through the intervention of her brother and two aunts who informed their employers who, in turn, informed the parents of the boy in question asking them to advise their son.

After the death of her mother Leela decided to stay back in Sri Lanka. She used her accumulated earnings from overseas work to complete the building of her new house, help her grand children and establish herself as a leading money lender in the area. She also managed some of the funds remitted by her family members working in Dubai using those funds for money lending where necessary. She also closely monitored the activities of the husbands and children of two sisters who were still working in Dubai, sometimes causing their resentment in the process. She was however perceived as a matriarch who helped the entire extended family to take advantage of overseas employment as 
a means of improving their life circumstances. She has been an unusually dynamic and adaptive woman who served as the central part of two generations of migrant workers from the same kinship network.

\section{CONCLUSION}

This study clarifies that, working abroad exerts an influence on the individual the community and the society. (Wanninayake, 2001) But this study attempted to explore the impacts of the family, kinship groups and social institution on international labor migration and how they exist while facing broad and modern social forces. To do this the researcher used a care study serving around a single female migrant who remains at the centre of a kinship circle. That includes several other female migrants and their families. The factors that led to successes and failures were examined from a practical and an in-depth analysis approach.

The freedom and opportunities for women migrating abroad for work are permitted though the structural relationship in the families. The essential determinants are arrangements to take care of their children, their security and opportunities for children to attend school without disruption. For these matters co-operation of family members is of paramount importance.

On the other land, money earned by migrant women on the basis of their objectives, world be handled by the head of the house hold or the recipient whose money management skills one of paramount importance. Decisions on savings, investment and effective use of money is beyond the decisions of the money earner.

In this care study,Leela was the focal point and most of her family members had made significant contributions to perform the basic tanks including consent to go abroad freedom to travel and co-operated in all matters.Leelas mother cooperated by working after the children her sisters provided financial assistance in addition to taking care of Leelas mother and children. In return for this help Leela had spent her earnings to give them money, presents and also repayment of loans. All these had contributed to father strengthen kinship relationships and linkages.

On the other hand Leela supported her relatives particularly her sisters to find employment abroad by extending her support, and in addition ensured their security, protection to avoid any unwanted consequences.Leela collected money for her trip from her relatives. Such on approach saves migrant women from money leaders and the employment agencies keen to exploit their victims to the maximum extent. Escaping such exploitation has contributed to success achieved by Leela and her relatives.

During the second place of Leela care study the importance of family and kinship networks on labour migration particularly with regard to women, emerges on a significant factor. As a grand mother Leela took care of the children in addition to serving on the aunt for her sisters children. Such support and help further strengthened their kinship relationships.

The importance of kinship relation ships again emerges with regard to saving money, investment and consumption licked sound financial management. When Leela migrated in handling Leela remittances the family members had not directly contributed. The family members were involved only in consumption. So she had to engage in savings by herself. However, she was able to lay a 
foundation for her house, and buy some tools with her savings. What she did appears to be preparation of a background to reap long term benefits.

To some extent Leela influenced financial management in her sister families, but it was influenced by behaviors of her bothers-in law. In determining successes and failures activities of brother-in-law were significant. Although Gamini had Leelas support for the initial investments, he preferred to manage his reasonless on the basic of his own decisions. Gamini very cleverly looked after his children while investing his reasonless wisely. It contorted to success of booth himself and his family. In his movement towards success, in the early stages some limitation were imposed on kinship relation and there were some conflicts too. This strained the relationship between Leela and Gamini to some extent. But all the essential stages they got together and worked in co-operation. After achieving his goods, Gamini started helping his relatives.

Jinadasa as family also enjoyed earnings similar to Gamini family. However Jinadasa behavior was different. Although he wanted Leela cooperation, he could not control his behavior of drinking with his friends. However Leela continued to support the family and Jinadasa will see no progress till his wife returns home. He failed to shoulder his family relationship adequately, and was therefore dependant as Leela.However he maintained very good kinship relationships and continued to keep his friends too.

During the second place of Leela care study her competence in financial management can be observed. She had sent her son and two daughters to work abroad. Although she looks a small portion of their remittances for her own use, she did a very cleaver job in savings, investment and effective renounce use. She was able to construct a house, frails it and though lending activities build up a lending business of her own. She saves all the money remitted by her daughter, to support her marriage in the future. This is an investment for the future.

This care study indicates low kinship network relationships influence migrating women and the success of their families.Leela overcome many challenges through infusing effective kinship network relations in the location where her family members were employed. Though improving kinship net work relationships Leela was able to over all family welfare security and well being of children and proper use of earnings to lay the foundation for successful living.

Several other findings also emerge from this study. However much Leela helped, Gamini refused her. It indicates that financial management can gradually create a stress on family. Kinship, relationship. When money flows to an individual, changes in behaviour, feelings and attitudes and likely an illustrated by Gamini behavior. How ever Leela's sister did not display such indifferences. This suggests that there are individual differences in keeping relationships in the face of stresses. There were indifferences between Leela and Jinadasa regarding This indicates that people behave on the basic of their attitudes. Some researches findings have revealed that the degree of unselfishness expected of remain within kinship relation have to face challenges.

Leela loved her son, doughter and their children. While displaying affection to the grand children and sending then to school, she expected money and presents for herself. She used her sons remittances to start her own business. In the competitive society of today, the craving for money becomes very 
clear.Leela did not want to be dependant an others and therefore established her own enterprise.

On the other hand Gamini wanted to handle and manage his wife remittances by himself. He did not want any one to interfere in these matters. However after strengthening his economic status to stability he re-enters the kinship relationships by extending help to the relatives. After achieving prosperity he desired to renew the kinship relationship. This clarifies that the true challenge to kinship network relationships is not the women's (temporary) departure from the family, but these related to the economic well being of their families.

When the consequences of Sri Lankan women migrating abroad are considered if appears that changes occur in individuals, family, community and social activities. These changes may challenge social relation, relationships. On the other hand, these network relationships have a determining influence on the degree of success or failure achieved by them.

\section{LIMITATIONS AND RECOMMENDATIONS}

This study relied on a case study approached, and analyzed the case of Leela to identify migration of women and their faily dynamics. However, the findings here coulf not be generalized to a larger proportion. Thus, scholars encourage similar future studies with mixed methods to gain more insights into this phenomenon.

\section{REFERENCES}

Appaurai, Arjun. 2001. Globalization. Durham and London, UK: Duke University Press.

Gamburd, Michele. 1995. The kitchen spoon's handle: Transnationalism and Sri Lanka's migrant housemaids. Ithaca and London, UK: Cornell University Press.

Colen, Shelee. 1995. Like a mother to them: stratified reproduction and West Indian childcare workers and employers in New York. In: Ginsburg, Faye D., and Rayna Rapp. (eds.). Conceiving the new world order: The global politics of reproduction. Berkeley, US: University of California Press.

Collier, Jane, and Sylvia Yanagisako. (Eds.). 1987. Gender and kinship: Essays toward a unified analysis. Stanford, US: Stanford University Press.

Gunatilleke, Godfrey. (ed). 1992. The imapct of labour migration on house-holds: A comparative study in seven Asian Countries. Tokyo, Japan: United Nations University Press.

Lee, Susan K., Cheryl MR Sulaiman-Hill, and Sandra C. Thompson. 2013. Providing health information for culturally and linguistically diverse women: priorities and preferences of new migrants and refugees. Health Promotion Journal of Australia 24, no. 2: 98-103.

Sri Lanka Bureau of Foreign Employment (SLBFE). 1997-2014. Statistical hand book on foreign employment. Colombo, Sri Lanka: Research and Development Division.

Syed, Iffath Unissa. 2016. Labor exploitation and health inequities among market migrants: A political economy perspective. Journal of International Migration and Integration 17, no. 2 (2016): 449-465.

Wanninayake, H.M.K.S. 2001. The factors affecting successes and failures of returnee women from the Middle-East: A sociological study of Middle-East employment in Kurunegala District. A Research Report, Colombo, Sri Lanka: Poverty Impact Monitoring Unit (PIMU).

Wanninayake, Santa. 2006. Women, family and the sociological background of Middle-East migration. Samaja Vimasuma 12, 157-186. 